\title{
Etnográfica
}

Revista do Centro em Rede de Investigação em

Antropologia

vol. $17(2) \mid 2013$

Vol. $17(2)$

\section{A legitimação das aparições da Virgem Maria: estratégias e agências}

The legitimization of Virgin Mary's apparitions: strategies and agencies

\section{Lílian Sales}

\section{(2) OpenEdition \\ Journals}

\section{Edição electrónica}

URL: https://journals.openedition.org/etnografica/3136

DOI: 10.4000/etnografica.3136

ISSN: 2182-2891

\section{Editora}

Centro em Rede de Investigação em Antropologia

\section{Edição impressa}

Data de publição: 1 junho 2013

Paginação: 317-339

ISSN: 0873-6561

\section{Refêrencia eletrónica}

Lílian Sales, «A legitimação das aparições da Virgem Maria: estratégias e agências», Etnográfica [Online], vol. 17 (2) | 2013, posto online no dia 19 junho 2013, consultado o 09 fevereiro 2022. URL: http://journals.openedition.org/etnografica/3136 ; DOI: https://doi.org/10.4000/etnografica.3136

\section{(c) (i) (8)}

Etnográfica is licensed under a Creative Commons Attribution-NonCommercial 4.0 International License. 


\section{A legitimação das aparições da Virgem Maria: estratégias e agências}

\section{Lílian Sales}

Neste artigo analisamos a importância da Igreja Católica, por meio de seus representantes e movimentos, na produção de teorias e no estabelecimento de práticas devocionais sobre as aparições marianas. Por meio da observação dos argumentos e devoções dos agentes católicos e da intermediação realizada pelos movimentos leigos, como a Renovação Carismática Católica, observamos o importante papel desempenhado pela instituição católica para a constituição da legitimidade das aparições da Virgem Maria. Além disso, investigamos como a presença de novos modelos de ação entre os agentes católicos contribui para a manutenção dos fiéis no catolicismo, tornando-os fundamentais para a Igreja na atualidade e servindo para a sua continuidade.

PALAVRAS-CHAVE: aparições marianas, Igreja Católica, Renovação Carismática Católica, papa João Paulo II, René Laurentin.

The legitimization of Virgin Mary's apparitions: strategies and agencies The article analyzes the importance of the Catholic Church, through its agents and movements, in the production of theories and the establishment of devotional practices about Virgin Mary's apparitions. By the observation of arguments and devotions of Catholic agents and the intermediation performed by lay movements, such as the Catholic Charismatic Renewal, the article observes the important role played by Catholic Church to establish the legitimacy of the apparitions of the Virgin Mary. In addition, the new models of action between the Catholic agents are investigated, focusing on their contribution to the maintenance of believers in Catholicism, making them essential for the Church nowadays.

KEYWORDS: Our Lady's apparitions, Catholic Church, Catholic Charismatic Renewal, René Laurentin, Pope John Paul II.

SALES, Lílian (lisales@usp.br) - Universidade Federal de São Paulo (Unifesp), Brasil. 
AS APARIÇÕES DA VIRGEM MARIA SÃO FENÔMENOS BASTANTE ANTIGOS no catolicismo. Historiadores demonstram a existência de manifestações de contato entre a Virgem e os humanos desde a Idade Média. Apesar disso, elas não são fenômenos consensuais no âmbito do catolicismo, pelo contrário, estas manifestações são alvo de intensas controvérsias envolvendo teólogos, sacerdotes, bispos. Muitas delas, inclusive, permanecem à margem da oficialidade católica, não sendo jamais consideradas verídicas nem recebendo o reconhecimento oficial.

Neste artigo observaremos que a Igreja Católica desempenha um papel importante para a constituição da legitimidade destes fenômenos. Este processo de legitimação mobiliza várias instâncias, grupos e representantes da Igreja. A aceitação ou rejeição de uma aparição é alvo de disputas internas, sendo cada caso analisado, debatido, defendido ou combatido antes de ser reconhecido. Trata-se, pois, de um universo marcado por controvérsias que contrapõem defensores e opositores dos "eventos extraordinários", entre os quais se encontram as aparições de Nossa Senhora.

Nos remetemos a uma citação de Pelletier, que nos lembra “que l'Église, comme toute institution historique, est aussi un champ d'affrontement où le rapport de forces se noue autour de la définition d'une légitimité croyante" (Pelletier 2005: 216). Não é nossa intenção neste artigo descrever todo o campo de disputas constituído pela Igreja Católica em torno das aparições de Nossa Senhora, mas apenas destacar que não existe um posicionamento único e homogêneo a seu respeito, pelo contrário, cada caso, mesmo os que parecem mais consensuais - como Lourdes e Fátima, por exemplo - ainda são alvos de discussões entre os teólogos marianos. ${ }^{1}$

Os dados para a escrita deste artigo foram obtidos a partir de um longo trabalho de campo, entre 2003 e 2008, pela observação dos rituais, conversas e entrevistas com os participantes, peregrinos e videntes de aparições marianas no Brasil e na Europa. Por meio deste trabalho percebemos que as aparições marianas não são fenômenos isolados, mas inseridos em uma rede pela qual circulam pessoas, informações e as manifestações.

Notamos a existência de importantes "nós", ou "elos" nesta rede, que assumiam papéis de destaque na produção da legitimidade das manifestações. Entre eles se destacavam a Igreja Católica, por meio de seus sacerdotes e teólogos, e o movimento carismático. A importância da Igreja Católica e seus representantes foi constatada devido à leitura de processos e de documentos teológicos sobre as aparições da Virgem, bem como dos pareceres de teólogos e cientistas sobre elas, especialmente sobre as aparições europeias reconhecidas pelo Vaticano.

1 Lourdes e Fátima são duas aparições marianas paradigmáticas. Ambas são oficialmente reconhecidas pelo Vaticano e se transformaram nos maiores santuários de Nossa Senhora na Europa. Além disso, são percebidas como “aparições modelo” pelos frequentadores desse tipo de manifestação. 
Já a centralidade do movimento carismático foi constatada durante todo o campo, sendo observada sua importância na organização dos rituais e o seu protagonismo na organização de peregrinações aos santuários de aparição, relatado em entrevistas e conversas com os participantes.

Neste artigo nos deteremos especialmente no papel dos representantes da Igreja Católica, mencionando com menos vagar o papel da Renovação Carismática Católica (RCC) nas aparições. Nosso foco estará, pois, direcionado para uma dimensão destas controvérsias: o importante papel desempenhado por membros eminentes da Igreja Católica e de grupos leigos, especificamente a RCC, no processo de construção da legitimidade destas manifestações. Demonstraremos a centralidade da presença da Igreja, por meio de seus representantes e grupos, na produção de teorias e práticas devocionais sobre as aparições marianas, colocando categorias e devoções em circulação no âmbito do catolicismo em geral.

Há importantes defensores das aparições na alta hierarquia católica - nos deteremos em dois deles, o teólogo René Laurentin e o papa João Paulo II -, cujas argumentações e devoções circulam entre os participantes desses fenômenos, sendo reproduzidas por eles.

Neste aspecto, será também nossa tarefa demonstrar o importante papel de mediação desempenhado pela RCC neste processo. Este movimento, por meio de sua organização e de seus contatos, possibilita a circulação de conceitos que contribuem para a constituição da crença na veracidade destes fenômenos.

Assim, não é apenas no âmbito teológico que as discussões e disputas acontecem. Elas se estendem para outros níveis e setores da Igreja, desde a paróquia até o Vaticano, podendo ser observadas em posturas e políticas adotadas pelos sacerdotes - desde o pároco da comunidade até o papa. Existem, pois, diferentes planos de análise, desde um plano institucional mais distante - especialmente o Vaticano e as políticas e práticas estabelecidas por ele através de seu representante -, até um plano de análise mais próximo dos fenômenos, que ocorre nos locais das manifestações, nas relações estabelecidas com o bispo da localidade e os sacerdotes das proximidades.

As posturas adotadas nos diferentes planos exercem influência sobre as aparições, constituindo um fator importante para a atribuição ou não de legitimidade a um fenômeno. Dessa maneira, a interferência da Igreja sobre as aparições marianas aparece em diferentes âmbitos, desde o local, em que os sacerdotes e bispos das comunidades desempenham papel central, até um plano mais distante, como na defesa ou repúdio de cada manifestação por importantes teólogos, ou nas práticas do pontífice - especificamente João Paulo II - em relação a elas. Em cada um destes planos existem atores e grupos dispostos a defender e legitimar as aparições de Nossa Senhora. Elas possuem importantes defensores no corpo da Igreja, inclusive em sua alta hierarquia e entre os intelectuais católicos. 
No plano teológico uma figura se destaca: o padre René Laurentin, considerado o mais importante teólogo mariano da atualidade e ardente defensor das aparições de Nossa Senhora, formulador e disseminador de importantes ideias e crenças sobre as aparições. Suas concepções sobre as manifestações marianas circulam pelo mundo.

Representantes da Igreja e grupos leigos são parte engajada nestas manifestações, existindo, inclusive, calorosos debates teológicos sobre cada manifestação. Não esgotaremos neste trabalho toda a controvérsia sobre as aparições marianas, mas sim nos focaremos em um aspecto dela: como, em meio a este caos de ideias, práticas e devoções, vai sendo construída a legitimação das manifestações marianas.

Para isso problematizaremos esta questão, e não a polarizaremos entre a aceitação ou rejeição, mas tentaremos compreender quem são os agentes envolvidos e como eles se posicionam, qual é a forma como formulam e apresentam seus argumentos. Demonstraremos, por um lado, como estes discursos aparecem publicamente, quais são as estratégias mobilizadas para a sustentação e visibilidade dos argumentos e, por outro, quais os valores que são arregimentados no processo para torná-los legítimos.

Ainda com relação à instituição católica, em seu plano "oficial", não podemos deixar de mencionar a importância da figura de João Paulo II, que, por meio de sua devoção a Nossa Senhora e da sua peregrinação entre os santuários marianos, inclusive os de aparição, recoloca Maria como figura central do catolicismo - no plano institucional - e incentiva e legitima a devoção a ela entre os católicos. Por isso, nos deteremos também na análise das posturas de Karol Wojtyla sobre a Virgem Maria, especialmente sobre as aparições marianas. ${ }^{2}$

A importância da Igreja na produção da legitimidade das aparições marianas já havia sido observada por autores que analisaram estes fenômenos na França no século XIX. Vale a pena retomar alguns pontos desta análise.

\section{CONTINUIDADE SIMBÓLICA NAS APARIÇÕES MARIANAS}

Os estudiosos marianos afirmam a existência de um modelo de aparições de Nossa Senhora formado no século XIX. Entretanto, não há unanimidade sobre a concepção de que as aparições marianas são fenômenos característicos do

2 As aparições não são fenômenos isolados, mas mantêm relações com uma série de manifestações do mesmo tipo, às quais devem estar conectadas para obter legitimidade. Especialistas que analisaram as aparições na atualidade destacam que esses fenômenos têm aumentado nas últimas duas décadas (Steil, Mariz e Reesink, 2003). Zimdars-Swartz (1991), ao analisar as aparições de Nossa Senhora em Medjugorje, afirma a existência de um surto de aparições marianas nos últimos anos - vale a pena destacar que esse surto de aparições, a partir da década de 1980, é simultâneo ao momento em que o movimento Renovação Carismática Católica se expande e ganha força, não apenas no Brasil, mas em todo o mundo. 
período mencionado. Barnay (1999), em sua obra Le Ciel sur la Terre: Les apparitions de la Vierge au Moyen Âge, afirma que as aparições de Nossa Senhora estão presentes de forma significativa no catolicismo há séculos, tendo surgido no século IV e nunca deixando de existir, contabilizando mais de cinco mil relatos entre os séculos IV e XX. Segundo a autora, no Ocidente as visões se intensificam por volta do século X, e ocorrem principalmente para os monges, através de sonhos. Nesse período são construídas várias catedrais dedicadas a Nossa Senhora, é o momento de grande difusão da devoção a Maria no Ocidente. A figura da mediadora entre Deus e os homens começa a se constituir. Ela é considerada responsável pelas relações entre os homens e a hierarquia celeste, por isso the pedem clemência, pois ela se encarregará de estabelecer o contato com o mundo divino.

A concepção de Maria como mediadora e como Mãe de Misericórdia é central nas aparições contemporâneas, sendo parte importante da simbologia mariana nestes eventos. Esta concepção foi observada com recorrência nos rituais de aparição, na fala dos videntes, bem como durante as conversas e entrevistas com os frequentadores.

Dessa maneira, constatamos que elementos importantes das aparições possuem origem bastante anterior ao período de formação de um modelo para estes fenômenos: o século XIX. Elementos simbólicos de longa duração no imaginário católico permanecem presentes nas manifestações atuais. A imagem da mãe mediadora é apenas um elemento desta simbologia; outros estudiosos, como Ruth Harris (2001) em seu estudo sobre Lourdes e Elisabeth Claverie (2003) sobre a aparição de Medjugorje, também demonstram a importância dos elementos de continuidade para o reconhecimento da legitimidade destas aparições.

Assim, apesar de o século XIX ser considerado inaugural por alguns autores, importantes elementos simbólicos que constituem as aparições não são novidades estabelecidas na época moderna. A novidade está na utilização dada a estas manifestações por membros do clero. Este é um momento importante para as manifestações da Virgem, devido ao empenho de representantes da Igreja Católica. Não se trata apenas de um investimento na regulação e controle dos fenômenos, embora este também estivesse presente, mas sobretudo nas aparições como fenômenos representativos da existência e da manifestação do extraordinário e do sobrenatural no mundo, em um contexto em que a ciência e a razão ganham espaço e legitimidade. As aparições de Nossa Senhora representam a fé contra o racionalismo e o positivismo. Assim, apesar da longa história destas manifestações no catolicismo, o século XIX representa um momento específico de organização de um padrão para estes fenômenos, processo no qual alguns agentes da Igreja assumem papel de destaque. 


\section{A IGREJA E AS APARIÇÕES DO SÉCULO XIX}

No século XIX ocorre o reconhecimento de algumas aparições que se estabelecem como marcos para o catolicismo. Estas manifestações ocorrem na França, onde a Igreja reconhece sucessivamente três episódios: Rue du Bac, em 1830 , La Salette, em 1846, e Lourdes, em 1858. O envolvimento do clero com as aparições foi central para o reconhecimento destas manifestações. Embora os fenômenos de contato entre a Virgem e os homens já estivessem historicamente presentes no catolicismo, representantes da Igreja intervêm de forma direta em prol das aparições neste período.

A intervenção da Igreja, buscando regular as aparições, vinha acontecendo desde o início da época moderna. Já no século XVIII, Bento XIV instituiu critérios para a avaliação da autenticidade das manifestações, reconhecendo a sua legitimidade apenas após uma longa e rigorosa avaliação canônica. ${ }^{3}$ Entretanto, a novidade ocorrida no século XIX refere-se não à tentativa de controle da Igreja sobre estas manifestações, mas à estratégia adotada por parte do clero de utilizá-las como modelo de fé.

Esse é um fato importante. Segundo Albert-Llorca (2001), especialmente na França, houve uma estratégia da Igreja para reconquistar seus fiéis por meio da utilização das aparições marianas. Nas palavras da autora, as aparições "dão um novo impulso ao culto mariano e tentam relançar, contra o cientificismo, a crença nos milagres" (2001: 56). O interesse da Igreja por estas manifestações surge, pois, como uma reação ao cientificismo que vem ganhando espaço neste contexto.

A intervenção sobre as aparições marianas ocorre principalmente por meio de uma rede de clérigos que se envolve com as manifestações. Segundo Gillet (1994), essa rede, composta principalmente por padres e bispos, engaja-se no reconhecimento e na divulgação do "fato sobrenatural que ocupa toda a França" e que estabelece relações entre as aparições ocorridas na Rue du Bac (Paris), La Salette e Lourdes. Especialmente sobre La Salette, o autor demonstra a importância do envolvimento do clero da região e de pessoas de credibilidade que estão convencidas da veracidade das aparições, como o bispo de Grenoble, pessoa pública importante que se engaja na defesa da manifestação. Segundo este autor, é esta mesma rede que estabelece a conexão entre La Salette e outras manifestações ocorridas pouco antes na França.

As três aparições mencionadas, conectadas por meio de uma rede de divulgação estabelecida pelos clérigos, são consideradas pelos historiadores do catolicismo - como Albert Llorca (2002) - como inaugurais. No entanto, notamos que as três aparições em questão possuem mais elementos de disparidade do

3 Nesta avaliação são consideradas a personalidade do vidente, o conteúdo das manifestações e a finalidade das aparições. 
que de continuidade, especialmente a aparição da Virgem para Santa Catarina de Labouré, na capela da Rue du Bac, em Paris. A conexão e a continuidade entre elas foram estabelecidas pelos clérigos, como demonstrado por Gillet, e não constitutivas dos fenômenos em si.

Tomamos como exemplo a aparição da Rue du Bac, mais conhecida no Brasil como "Medalha Milagrosa", que possui características mais próximas das visões de Maria para religiosos, como as existentes no período anterior, do que das aparições modernas. Trata-se de uma aparição privada para uma freira, dentro de uma capela - segundo os relatos, Nossa Senhora aparece para a Irmã Catarina de Labouré na capela da Rue du Bac e lhe pede que seja cunhada uma medalha em seu nome.

O estudo realizado por Gillet (1994) demonstra que as características da aparição da Rue du Bac são semelhantes às das visões privadas para religiosos - como as visões medievais, ela acontece no âmbito de um convento, para uma freira, e possui um caráter privado, e não público, sendo a mensagem destinada exclusivamente a Catarina. A publicização desta manifestação foi realizada pelo clero, que contribuiu para o reconhecimento da aparição e atribuição do poder milagroso à medalha.

Gillet demonstra, em seu livro La rumeur de Dieu: Apparitions, prophéties et miracles sous la Restauration, que a conexão existente entre elas foi estabelecida pelo clero. Por meio de uma rede de contatos, "cria-se" uma ideia de conexão e de continuidade entre elas.

Sob esse ponto de vista, podemos considerar a aparição da Virgem da Medalha Milagrosa como um fenômeno de transição, pois, por um lado, possui as características dos relatos de visões para monges na Idade Média, por outro lado, tornou-se uma aparição pública, forjada e divulgada pelo clero. Vale lembrar que o seu caráter público não está no fenômeno em si, mas no empenho do clero em difundi-la.

Dessa maneira, as semelhanças entre as manifestações se tornam evidentes devido à construção destas aparições realizada pelo clero - Rue du Bac, Lourdes e La Salette - como um fenômeno milagroso único presente na França. Nas aparições contemporâneas, a importância dos representantes da instituição católica na produção de ideias, valores e práticas sobre estes fenômenos está presente. Este novo ciclo de aparições tem relação com agentes e movimentos centrais da Igreja.

\section{RENÉ LAURENTIN E A DEFESA DAS APARIÇÕES DE NOSSA SENHORA}

Padre René Laurentin é o mais notório defensor das aparições marianas na atualidade, sendo um dos mais iminentes teólogos marianos contemporâneos, possuindo livros publicados sobre diferentes manifestações. Desde a década de 1940 ele pesquisa e escreve sobre as aparições da Virgem pelo mundo. 
A sua importância vai além do campo teológico, pois suas ideias e teorias circulam pelo mundo católico, em grande parte devido a sua proximidade com o movimento carismático. A grande maioria de suas obras tem grande penetração nos Estados Unidos, sede da coordenação internacional do movimento, sendo disseminada entre os carismáticos por todo o mundo. Além disso, ele próprio também circula, realizando palestras sobre Nossa Senhora, sendo, atualmente, um dos mais importantes pregadores da devoção às manifestações extraordinárias da Virgem.

A antropóloga Elisabeth Claverie, em seu livro sobre as aparições de Medjugorje (2003), destaca que René Laurentin sempre esteve na contracorrente da teologia dominante, ao defender a figura de Maria no catolicismo. Ele faz a apologia das aparições marianas desde antes do Concílio Vaticano II, momento em que essa escolha representava um enfrentamento a outras correntes de espiritualidade, e continuando na fase pós-conciliar, em que a corrente que defendia o marianismo foi objeto de vários ataques. Laurentin enfrentou estas batalhas por meio da organização de dossiês sobre as aparições do século XIX, a princípio, estendendo-se a outras manifestações em seguida, como Medjugorje.

O ponto de partida do teólogo foi a aparição de Lourdes, sobre a qual montou um enorme dossiê, publicado em treze volumes (Laurentin 1957-1961, 1965), nos quais busca demonstrar a veracidade das aparições por meio do que ele denomina "provas". Essa metodologia de trabalho é repetida na análise de outras manifestações. Laurentin utiliza-se de uma metodologia positivista, fazendo um grande levantamento de "evidências" sobre cada evento para demonstrar a sua autenticidade. Trabalha, segundo Claverie, em um registro característico da "modernidade", adotando um modo de enunciação de tipo jurídico/judiciário, que começa, de modo geral, pela comprovação da "credibilidade” dos videntes. Com base na análise destes dados ele junta elementos que, na sua perspectiva, comprovam a autenticidade das manifestações.

Além das publicações sobre a aparição de Nossa Senhora em Lourdes - doze volumes com documentos, entrevistas, originais dos interrogatórios, descrição detalhada dos milagres, a personalidade da vidente Bernadette, entre outros -, Laurentin também produziu obras sobre as aparições de Pontmain (1970), La Salette (Laurentin e Corteville 2002) e Rue du Bac (1976), aparições marianas acontecidas na França no século XIX. No entanto, o teólogo não se detém apenas nas manifestações reconhecidas pelo Vaticano, sendo o autor um importante defensor da aparição da Virgem na vila de Medjugorje, tendo publicado vários livros, desde que se iniciaram as aparições, em 1981, buscando demonstrar a sua veracidade. ${ }^{4}$ Laurentin é o grande especialista e defensor

4 Apesar de a cidade ter se transformado em um dos maiores santuários europeus, a aparição não foi reconhecida como verídica pelo Vaticano. Há uma forte disputa entre dois importantes [continua] 
das aparições, tendo escrito mais de cem obras sobre este tema. Uma de suas obras mais recentes é um dicionário sobre as aparições marianas (Laurentin e Sbalchiero 2002), no qual relata e analisa 2400 aparições com a ajuda de especialistas de diversas áreas.

O autor se utiliza de uma aparelhagem de cunho científico, seus dados são coletados, demonstrados e analisados como "provas científicas". Recorre a gráficos, tabelas, pareceres de especialistas - médicos, psicólogos, historiadores -, utilizados como comprovações. Por fim, monta um processo a fim de garantir a credibilidade de sua demonstração.

No entanto, constatamos que o teólogo também possui uma posição sobre o tratamento dado aos chamados "eventos extraordinários" pela Igreja Católica na atualidade, considerando que esses fenômenos ou são deixados de lado pelo catolicismo no mundo contemporâneo, ou tratados com desconfiança. Quando ele se refere à Igreja, está na verdade se referindo à corrente teológica majoritária no catolicismo atual, que defende uma postura de prudência diante das manifestações "milagrosas".

Laurentin, ao defender as aparições, estabelece um debate interno ao catolicismo, em que questiona o empenho dos bispos em analisar estes fenômenos e a postura da corrente teológica majoritária na Igreja, acusada de colocar os fenômenos extraordinários em segundo plano. A sua frase "A Igreja não gosta do milagre" (Laurentin e Sbalchiero, 2002: 8), presente na introdução do Dictionnaire des miracles et de l'extraordinaire chrétien, representa bem sua posição.

Em suas obras, o autor parte de casos específicos de aparições para defender sua posição mais geral sobre as manifestações marianas e os fenômenos extraordinários; essa é a sua estratégia discursiva. Analisamos os argumentos utilizados por Laurentin em defesa da veracidade das aparições a partir da leitura de algumas de suas obras - sobre a aparição de Lourdes, Pontmain, La Salette e Medjugorje - e constatamos padrões comuns em seus argumentos.

\section{Laurentin e a defesa das aparições da Virgem}

A leitura das obras de Laurentin sobre as aparições de Nossa Senhora nos permitiu sistematizar os argumentos utilizados por ele em defesa destes eventos. Cada obra é constituída por uma série de documentos que buscam comprovar a veracidade de uma determinada aparição, a sua leitura chegando a ser exaustiva, pela grande quantidade de "evidências" que vão se acumulando ao longo dos textos.

O autor constrói sua argumentação utilizando-se, em cada caso, de dados que se aproximem dos critérios adotados pela Igreja para demonstrar a veracidade 
das aparições. Utilizaremos como exemplo a análise da aparição de Pontmain, em que o número de provas recolhidas na época da manifestação foi escasso. ${ }^{5}$ $\mathrm{O}$ autor se apega em dois elementos para comprovar a sua veracidade: a ortodoxia da mensagem e, principalmente, o "testemunho de fé" representado pela vida dos videntes após as visões.

No que se refere à ortodoxia da aparição, houve apenas uma manifestação da Virgem, sem a transmissão de mensagens. O autor, então, se foca na imagem observada pelas crianças, descrevendo sua figura, que aparece chorando, muito triste, de uma tristeza indescritível. Ele gasta várias páginas de sua obra na descrição da imagem da Virgem, buscando aproximar a imagem da aparição de Pontmain e a imagem legítima de Nossa Senhora das Dores. A "tristeza indescritível" da Virgem mencionada por Laurentin é somente comparável à de uma mãe que presenciou a morte de seu filho. Dessa maneira, quando associa as características de Maria em Pontmain com a imagem de Nossa Senhora das Dores, procura transferir o valor da imagem consagrada no catolicismo para essa aparição.

Outro elemento utilizado pelo autor é a vida dos videntes após a aparição. Esse é o aspecto em que o autor mais se detém, dedicando a ele parte significativa de sua obra. Segundo ele, todos os videntes tiveram uma vida de acordo com os padrões considerados corretos pelo catolicismo.

Dois processos de avaliação foram abertos pela diocese local sobre a aparição de Pontmain, ambos obtendo parecer favorável. O primeiro logo após as manifestações, em que as quatro crianças foram interrogadas separadamente, tendo o analista encontrado "coerência e boa fé" em seus relatos, elaborando um relatório favorável para o bispo. O segundo processo ocorre em 1918, quando as testemunhas ainda vivas foram ouvidas e os quatro videntes examinados por professores de escolas de medicina e novamente interrogados. Nas palavras do autor, "tudo ia bem. Pontmain continuava um lugar de fervor. Não havia existido nem epidemia de visionários, como em Lourdes. Tudo estava claro, os videntes não tinham nenhum segredo. Todos tinham entrado na vida adulta sem visão nem êxtase, tinham seguido uma vida cristã exemplar" (1970: 77).

A colocação anterior do autor aponta dois aspectos importantes de sua análise: por um lado, o enfoque na vida e na postura dos videntes para demonstrar a "santidade" desta manifestação. Por outro lado, a relação entre a aparição de Pontmain e duas outras aparições ocorridas na França no mesmo período: Lourdes e La Salette, ambas também reconhecidas pelo Vaticano.

$\mathrm{O}$ autor admite que a característica central em Pontmain seja a fidelidade cristã dos videntes, pois dois deles tornaram-se padres, dedicando a vida à

5 A aparição de Nossa Senhora na vila francesa de Pontmain aconteceu em 17 de Janeiro de 1871. Segundo o relato oficial da aparição, durante três horas, quatro crianças (Eugène e Joseph Barbedette, Françoise Richer e Jeanne-Marie Lebossé) estiveram em contato com a Virgem. 
Igreja. É sobre eles que Laurentin se centra, demonstrando os seus "atos de fé cristã" como provas da autenticidade da manifestação. Assim, nada na vida dos videntes depõe contra eles; pelo contrário, tudo serve como comprovação de que a Virgem realmente lhes apareceu, pois levaram uma vida dedicada à Igreja, como, na sua concepção, é esperado de alguém que tenha estado em contato com Nossa Senhora.

Voltando à citação anterior, o autor também busca atribuir valor a Pontmain, estabelecendo um contraponto com outras duas aparições francesas contemporâneas, Lourdes e La Salette, especificamente no que diz respeito à postura dos videntes e aos eventos que sucederam ao período das aparições. Isso porque, no caso de La Salette, uma das videntes, Mélanie, depois de adulta afirmou continuar tendo visões da Virgem, publicando inclusive um livro com as "novas" revelações. Essas novas visões foram severamente condenadas pela Igreja, sendo a vidente acusada de "má-fé" e de querer tirar proveito delas. Já no caso de Lourdes ocorreu a proliferação de visionários após as revelações feitas para Bernadette, várias pessoas afirmavam ter visões da Virgem na grota de Lourdes. Todos eles são considerados falsos e foram reprimidos pelos representantes da Igreja, reconhecendo-se apenas Bernadette como a vidente verdadeira.

Laurentin se utiliza desses eventos turbulentos e reprimidos pela Igreja para demonstrar a "santidade" dos videntes e do episódio de Pontmain. Lá nunca houve problemas com as crianças nem o surgimento de "falsos" visionários.

Apesar de centrar-se na vida e na coerência dos videntes, o autor não abandona outras evidências que ajudem a legitimar a aparição. A existência de milagres comprovados conta muitos pontos na produção da legitimidade de uma manifestação e, embora no caso de Pontmain não existam milagres comprovados, Laurentin faz uma lista de milagres atribuídos à Virgem de Pontmain.

Isso ocorre devido às concepções do próprio autor, que são compartilhadas por uma série de devotos, mas que diferem da concepção de milagre estabelecida pela Igreja - que exige uma comprovação do caráter sobrenatural do fato para considerá-lo milagroso. Para a maioria dos fiéis, o simples relato de uma graça recebida é suficiente para dar-lhe a característica milagrosa. Assim, mesmo não sendo "comprovadas", as histórias de graças importam para a crença na veracidade dos fenômenos.

Neste caso, apesar de o teólogo usar um aparato científico, seus interlocutores são também pessoas já convencidas da verdade das manifestações. Dialoga com peregrinos ou devotos das aparições, com pessoas que consideram que o milagre não necessita de provas da ciência, mas que se interessam pelos seus relatos. Por outro lado, essas justificativas também servem de apoio na defesa de suas concepções diante de pessoas que não creem nas manifestações, no âmbito do catolicismo e fora dele.

Neste aspecto, a inserção dos milagres não reconhecidos da aparição de Pontmain pode ser compreendida. Para os que consideram a veracidade das 
aparições não é preciso a comprovação dos milagres, apenas o seu relato basta. Entretanto, a prova nos moldes científicos importa para ambos - fiéis e teólogo como forma de demonstrar a verdade das aparições diante daqueles que não creem nelas. Laurentin, então, trabalha com os dois tipos de registro. Os critérios são utilizados de maneira a estabelecer um diálogo com dois tipos de interlocutores.

\section{Laurentin e seus interlocutores: o lugar do "extraordinário" na Igreja}

Atualmente há uma grande burocracia estabelecida pela Igreja para o reconhecimento dos milagres, o que dificulta cada vez mais a classificação de um evento como milagroso. Esse rigor é questionado por Laurentin, que possui uma concepção de milagre menos rigorosa e burocrática, oscilando entre a importância da comprovação de caráter científico e a centralidade da fé.

A dupla argumentação do autor fica ainda mais evidente na obra coletiva Vrais et fausses apparitions dans l'Eglise (Billet et al. 1976). Se, por um lado, discorre sobre os critérios estabelecidos, demonstrando sua importância para o bom julgamento dos fenômenos pela Igreja, por outro lado critica a posição de seus colegas sacerdotes na avaliação das aparições, responsabilizando-os pelo aumento no número de aparições rejeitadas. Assim, quando os critérios são utilizados para aprovar uma manifestação eles são valorizados pelo autor; porém, quando levam à sua reprovação ele acusa os avaliadores de excesso de rigor na utilização das regras.

A importância da análise recai, então, na exaltação dos casos prodigiosos. Cita como exemplo a aparição de Nossa Senhora de Lourdes, em que, segundo ele, a análise das curas por um comitê médico serviu para iluminar os casos extraordinários. O comitê busca comprovar os casos miraculosos, porém neste processo vários eventos são descartados. Esse fato, ao invés de deslegitimar o poder milagroso de Lourdes, reforça a excepcionalidade do milagre, pois os casos não considerados milagrosos exaltam a existência e legitimidade dos casos "comprovados".

Os dossiês realizados por Laurentin sobre as aparições são inspirados nos dossiês do comitê de análises médicas de Lourdes. Este escritório representa uma nova maneira de se analisar os eventos considerados extraordinários pela Igreja, baseada em comprovações médicas e científicas. Esse novo tipo de análise está relacionado com o momento em que ocorrem as aparições de Lourdes, e com o intenso debate estabelecido em torno delas, polarizando os representantes da Igreja e defensores do cientificismo na França do século XIX. Lourdes é emblema deste embate.

Diante deste aumento da legitimidade do cientificismo desde o século XIX, a Igreja passa a utilizar também métodos científicos para demonstrar a veracidade dos milagres. Em outras palavras, ela começa a utilizar-se dos critérios do 
"inimigo", representado pelo cientificismo, para legitimar algo - os milagres que antes estava exclusivamente no plano da fé.

A argumentação de Laurentin segue a mesma linha, ele precisa dos métodos e termos científicos para produzir a verdade da aparição. Apenas os termos da fé, desde o século XIX, não são mais suficientes para isso. A Igreja Católica, por meio de seus intelectuais, precisa operar com uma lógica semelhante à científica, por meio de evidências, provas, pareceres de especialistas, para conseguir produzir convencimento. Porém, como dito, permanece clara a posição do autor em defesa da fé.

A postura de Laurentin encontra importantes interlocutores na instituição. Neste aspecto, a centralidade da circulação de suas ideias e crenças numa rede, que possui a RCC como célula organizativa, possibilita a reprodução de suas teorias por todo o mundo. A concepção de milagre estabelecida pelo teólogo - menos rígida do que a presente na doutrina católica - é compartilhada pelos carismáticos.

A proximidade entre o vocabulário utilizado por Padre Laurentin e os seguidores do movimento carismático é exemplo disso. Os termos e expressões utilizados são os mesmos, bem como as justificativas para os milagres, como o chamado esquema de Gamaliel: "Se a empresa vem dos homens ela se autodestruirá, mas se ela vem de Deus, vocês não conseguirão destruí-la”. Ele usa este esquema ao se referir às aparições de Maria: se forem invenção humana não perdurarão, porém, se forem verídicas, não serão destruídas.

Este mesmo esquema é constantemente mencionado pelos carismáticos sobre os fenômenos milagrosos. Em nossa pesquisa constatamos que, logo que surge um fato considerado extraordinário - como uma pessoa que afirma ter visões de Nossa Senhora -, os carismáticos se mobilizam rapidamente para participar das manifestações. Eles não apenas participam, mas opinam e avaliam a veracidade ou não da manifestação, sendo um dos critérios utilizados justamente o esquema de Gamaliel.

Assim, Laurentin tem uma grande importância na defesa teológica das aparições de Maria, que repercute pelo mundo através da RCC e dos devotos de diferentes aparições. Entretanto, a devoção a Nossa Senhora e a suas aparições encontra apoio em outros setores da Igreja Católica, e aqui podemos citar especialmente a figura do papa João Paulo II, devoto publicamente declarado da Virgem e responsável por várias ações que incentivaram a sua devoção em todo o mundo católico.

\section{JOÃO PAULO II E AS APARIÇÕES MARIANAS}

Se René Laurentin é o intelectual defensor das aparições da Virgem, João Paulo II é o mais iminente devoto destes fenômenos. O papa, pelo seu exemplo de fé, atribui legitimidade a elas pela sua devoção. 


\section{João Paulo II: devoto e peregrino}

Para compreendermos a relação entre o papa João Paulo II e as aparições marianas devemos nos reportar a sua infância na Polônia, país de tradição católica, já que esse é o momento em que a sua devoção à Virgem Maria é estabelecida e consolidada. A devoção de Karol Wojtyla a Nossa Senhora advém de sua infância, de sua criação no catolicismo polonês. Philippe Portier (2006), em seu livro La pensée de Jean Paul II refere-se à infância de João Paulo II, mencionando sua devoção a Maria desde muito jovem. Segundo ele, o papa perdeu sua mãe muito cedo, e foi criado pelo pai dentro dos preceitos do catolicismo, participando diariamente da missa e das orações. Neste período, ele e seu pai também participam das peregrinações aos grandes santuários marianos da Polônia, como o de Czestochowa, onde se adora uma imagem negra da Virgem. Segundo Portier, a devoção mariana é, sem nenhuma dúvida, um traço do catolicismo polonês vivido intensamente por Karol. A intensidade de sua devoção o faz aderir à liga mariana de Wadowice e a orar diariamente à Virgem na capela próxima a sua casa.

A devoção do papa a Nossa Senhora, e em especial à Virgem Negra de Czestochowa, permanece durante toda a sua vida e ajuda a explicar algumas de suas atitudes como pontífice. No ano de 1999, por exemplo, João Paulo II consagra a Polônia à proteção de Nossa Senhora de Czestochowa. Além da forte adesão às práticas devocionais do catolicismo polonês, Karol também realiza neste período a leitura de São Luis de Monfort, importante teólogo mariano, embasando a sua devoção a Maria em conhecimentos teológicos que o acompanharão durante a sua vida.

A devoção do papa é retomada e explicitada em suas atitudes como sacerdote, bispo e papa, dedicando sua vida religiosa a Maria. Em 1958, quando se torna bispo, proclama-se "totus tuus" (todo seu) a Maria, dedicando seu episcopado à Virgem. A mesma dedicatória é refeita vinte anos mais tarde, quando inicia o seu pontificado. Essa devoção lhe é tão cara que em seu brasão de líder do Vaticano se observa um M, de Maria, bem como a inscrição "Totus tuus".

Outras atitudes de João Paulo II durante o seu papado foram demonstrativas de sua fé e devoção a Maria. A mais explícita delas ocorreu após a sua sobrevivência ao atentado a tiro sofrido em 1981, em que atribuiu a sua salvação a Nossa Senhora de Fátima, uma aparição. Seu relato foi muito repetido entre os católicos, e também bastante divulgado. Nele o papa se coloca

“... devedor da Santíssima Virgem. Poderia esquecer que o acontecimento na Praça de São Pedro ocorreu no dia e na hora em que, há mais de sessenta anos, se recorda em Fátima, em Portugal, a aparição da Mãe de Cristo para pobres pastores? Em tudo aquilo que aconteceu exatamente nesse dia notei uma extraordinária proteção e solicitude maternal. Esta mostrou-se mais forte do que a bala assassina" (Wojtyla, cit. em AAVV 1992: 116). 
Assim, para o papa, não foi uma coincidência a data do atentado - 13 de maio - ser a mesma da aparição de Nossa Senhora na vila de Fátima. Segundo ele, devido à intervenção da Virgem sobreviveu e saiu ileso da bala que o feriu gravemente. ${ }^{6}$

João Paulo II, considerando-se devedor da Virgem de Fátima, realizou uma peregrinação ao santuário português, para agradecer pela graça recebida. Nesta ocasião, exatamente um ano após o atentado, em 13 de Maio de 1982, depositou a bala que o havia ferido na coroa da Virgem de Fátima. Essa atitude de Karol Wojtyla repercutiu sobre a aparição portuguesa, promovendo-a. Ela passou a ocupar espaço na mídia internacionalmente, sua história foi recontada e relembrada.

O brasão e a peregrinação para Fátima, como cumprimento de uma promessa, são exemplos de ações de João Paulo II que contribuíram para a valorização da devoção a Nossa Senhora mundialmente. Suas palavras, afirmando que foi a "mão maternal de Maria" que desviou a bala "assassina", foram amplamente divulgadas e, com elas, a crença do sumo pontífice nas intervenções de Nossa Senhora na vida dos homens.

Após esta primeira peregrinação, o papa esteve mais duas vezes em Fátima, em 1991 e 2000, sempre no aniversário das aparições, tendo na sua última visita beatificado dois pastores videntes - Jacinta e Francisco. A devoção de João Paulo II a Nossa Senhora e as suas peregrinações são fontes importantes de legitimidade para as aparições marianas.

Além disso, a postura do papa agrega valor também a outras manifestações marianas, além de Fátima. Em nosso trabalho de campo observamos que nas aparições de Nossa Senhora no Brasil, como em Jacareí, a importância da devoção de João Paulo II é notada. ${ }^{7}$ Embora ele não tenha conhecido esta manifestação, por ser devoto confesso de Maria e das aparições as referências a ele são comuns durante os cenáculos. Há, por exemplo, mensagens de Maria especificamente sobre ele, como a seguinte: "deixem-se conduzir fielmente pelo magistério de meu querido João Paulo II, o Papa preparado e formado por mim para esses dias, e que é o meu filho mais querido". ${ }^{8}$ Assim, ele é considerado como um papa especial, sendo a sua proximidade com Maria sempre lembrada. A sua importância e suas ações se estendem para além dos santuários para os quais peregrina, atingindo inclusive as aparições não reconhecidas, como a de Jacareí.

As peregrinações de João Paulo II não foram exceções em seu pontificado, pelo contrário, elas eram extremamente comuns. Durante os vinte e seis anos

6 O atentado e a bala "assassina" ficaram extremamente famosos, sendo inclusive relatados em livros, como a obra Bala Santa, de Luís Miguel Rocha (2010).

7 A aparição de Nossa Senhora em Jacareí, no interior do estado de São Paulo, teve início no ano de 1991. Seu vidente era o então adolescente Marcos Tadeu, de 13 anos. A primeira visão ocorreu numa tarde, quando o menino voltava para a casa após a aula, e desde então se repete todo o dia, quando a "senhora do céu" lhe transmite alguma mensagem.

8 Fala de Marcos Tadeu, vidente de Jacareí, atribuída a Nossa Senhora. 
que Karol Wojtyla esteve à frente do Vaticano ele visitou cento e vinte e nove países e mais de mil localidades, tornando-se conhecido como o "papa peregrino". Em cada uma de suas peregrinações atraía uma multidão de fiéis.

Concomitante à valorização da peregrinação, há também uma política de incentivo aos santuários. A promulgação do novo Código de Direito Canônico, que regulariza a situação dos santuários de peregrinação e busca estimulá-los, ocorre durante o seu papado. João Paulo II desempenha um papel central neste processo, peregrinando entre os santuários. Sempre em suas visitas aos países passava por algum santuário importante da região, escolhendo estes locais para a realização de seus pronunciamentos oficiais. Quando esteve no Brasil visitou o santuário de Aparecida, procedendo de maneira semelhante na maioria de suas visitas aos demais países. Inclusive, o título de "papa peregrino" advém não apenas de suas viagens, mas de sua passagem por santuários nestas ocasiões, em peregrinação.

A atribuição de valor ao santuário pela sua devoção foi notada em nossas observações de campo nos santuários de Lourdes e Fátima, em que os postais que retratam o papa diante das imagens da aparição são colocados em destaque nas bancas de venda de lembranças, abundantes nestes locais. Pelos postais podemos perceber a importância da devoção do papa para os peregrinos, que fazem questão de comprovar esta devoção levando para casa os postais que demonstram a fé do papa.

\section{A "nova" peregrinação}

A peregrinação pelos santuários católicos foi uma característica marcante do pontificado de João Paulo II, bem como o aumento no número de canonizações e beatificações. Seu pontificado foi o que promoveu o maior número de canonizações nos últimos tempos. Não se trata exclusivamente de um dado numérico, mas de um investimento do Vaticano na produção de santos e beatos. A cada peregrinação, em cada santuário pelo qual passava, João Paulo II realizava uma canonização ou beatificação de um santo local, como foi o caso dos pastores videntes de Fátima.

Alguns autores o consideram como um papa que soube se valer das devoções do catolicismo popular, incentivando peregrinações, santuários, aparições, e promovendo canonizações e beatificações. Especificamente no que se refere à peregrinação, notamos a atribuição de novas características e sentidos para essa antiga prática do catolicismo. O papa não só peregrina pelos santuários como um devoto, mas considera que a Igreja deve peregrinar. As peregrinações de João Paulo II divulgavam a sua imagem e a da Igreja Católica pelos locais por onde passava.

A importância atribuída à peregrinação e os novos sentidos dados a ela são observados em suas posturas e políticas frente ao Vaticano. A encíclica Redemptoris Mater, escrita em 1987, é um exemplo disso. Nela o papa estabelece uma caminhada da Igreja, junto com Maria, rumo ao terceiro milênio 
(Wojtyla 1987), determinando uma dinâmica/programa de Maria e da Igreja que são indissociáveis. O foco desta encíclica é o movimento; segundo Wojtyla, a Igreja está em marcha, como Maria ao partir para as montanhas de Judá após a anunciação (1987). O papa usa a palavra "peregrinação" mais de vinte vezes, bem como "rota", "itinerário", "caminho", considerando que a Igreja está em caminhada, e Maria como o ponto de partida desta peregrinação.

Este ponto nos chamou a atenção, pois destaca a importância da peregrinação, porém não só dos fiéis, mas da própria Igreja, por meio de um movimento iniciado com Nossa Senhora. Essa é a ideia central da encíclica, oficializando a importância do peregrinar. Trata-se, pois, de uma concepção de peregrinação na qual não são apenas os fiéis que peregrinam em busca do sagrado, mas é o próprio sagrado que se movimenta pelo mundo - marcha, caminha, peregrina, como os termos que indicam movimento.

A bênção que o papa realizava pelos países em que passava, beijando o chão, também pode ser compreendida neste contexto significativo. Ele levava a sua bênção até os territórios, não era preciso que os fiéis fossem em busca dela no Vaticano, ela ia até eles, em seu país, através do próprio papa.

Essa forma de agir, embasada no movimento e na peregrinação, é também marcante das aparições marianas contemporâneas. Dois aspectos nos chamaram a atenção na observação desses fenômenos: a circulação das manifestações e a circulação de pessoas para os cenáculos. Essa circulação tem características de peregrinação, pois se trata da locomoção de pessoas para os locais onde ocorrem aparições da Virgem, porém não se trata apenas de mobilidade de pessoas para um santuário. Os fenômenos também circulam, ocorrendo onde estiverem os videntes, que circulam pelo mundo tendo visões e levando consigo a própria Virgem. As manifestações marianas atuais são marcadas pela fluidez e movimentação.

João Paulo II usa uma antiga prática católica, a peregrinação, sem se desfazer de seus antigos sentidos - pois demonstra a sua devoção, peregrinando e orando nos santuários -, mas também lhe atribuindo novas características, especialmente relacionadas ao movimento da Igreja e da fé, que não podem ficar paradas, elas também têm que caminhar. É uma peregrinação de duplo sentido, a do papa devoto para os santuários, mas também a do papa representante da Igreja para as localidades, levando a fé, a sua bênção, e uma multidão de fiéis.

Dessa forma, o papa é o exemplo do agir religioso contemporâneo em que a peregrinação ganha centralidade. João Paulo II peregrina pelos santuários e, como os eventos extraordinários, leva consigo o sagrado e a própria Igreja. Notamos a permanência da importância de elementos da tradição no agir religioso contemporâneo, como no caso da peregrinação, em que a devoção aos santos e a visita aos santuários são ainda importantes, mas a ela são agregadas características do mundo contemporâneo, como a circulação dos eventos e da Igreja. 


\section{A MEDIAÇÃO DA RCC:}

\section{DISSEMINAÇÃO DE IDEIAS E PRÁTICAS}

Neste ponto devemos discutir a importância da Renovação Carismática Católica para a reprodução e disseminação das crenças e práticas relacionadas à devoção às aparições. A centralidade da mediação do movimento carismático nas manifestações marianas foi constatada em diferentes aspectos, sendo em grande parte responsável pela organização dos fenômenos por meio da disseminação de informações, ideias e devoções.

Ampla bibliografia demonstra a importância das peregrinações, da circulação de pessoas, símbolos e ideias, muitas vezes por meio do movimento Renovação Carismática, para a constituição da legitimidade das aparições (Steil, Mariz e Reesink 2003; Almeida 2004). Em artigo anterior (Sales 2009) abordamos dois aspectos centrais destes fenômenos: a circulação das manifestações e a circulação de pessoas para os cenáculos - rituais em que acontecem as manifestações. Nosso esforço consistiu em sistematizar toda a mobilização que caracteriza as aparições e que se mostrou fundamental para a existência de uma série de manifestações marianas.

Se, por um lado, essa circulação tem características de peregrinação, pois se trata da locomoção de pessoas para os locais onde ocorrem aparições da Virgem, por outro lado, porém, não se trata apenas da mobilidade de pessoas para um santuário. Os próprios fenômenos também circulam, e junto a eles circulam símbolos, ideias e práticas.

As manifestações marianas atuais são marcadas pela fluidez: no que se refere ao espaço - ocorrendo onde estiverem os peregrinos - como também no tempo - não possuindo várias delas uma periodicidade fixa. Para serem realizadas dependem da eficiência de uma rede, ligada ao movimento carismático, que se articula para a organização do cenáculo e das peregrinações, responsabilizando-se pela divulgação, contatos e financiamento dos rituais.

Assim, pessoas e manifestações circulam e, nesta circulação, que se faz em forma de rede, destaca-se a intermediação do movimento carismático. Ele é o responsável pelo preparo das peregrinações, pela disseminação de informações e contatos e pela organização financeira dos eventos. Esta rede é complexa e extensa, utilizando-se de toda a estrutura da RCC, suas redes de rádio e televisão para a divulgação de roteiros turísticos para santuários marianos, bem como de seus recursos financeiros para providenciar viagens de videntes a esses santuários, ou para trazê-los para comunidades carismáticas.

A inserção nesta rede, marcada pela intensa circulação e troca de contatos por diferentes meios - redes de televisão e rádio, sites na Internet, jornais e revistas -, mostrou-se central para a existência do fenômeno, demonstrando aspectos de inovação das aparições contemporâneas em relação às aparições modernas (Sales 2009). 
Entretanto, neste artigo destacamos outro aspecto fundamental do movimento carismático para a legitimação das aparições marianas no mundo contemporâneo: as suas características organizacionais. As características organizacionais do movimento possibilitam a disseminação e a circulação de argumentos, imagens e notícias sobre as aparições. A RCC possui uma organização interna hierárquica, paralela e independente da hierarquia oficial da Igreja Católica. No topo dessa hierarquia está a Renovação Carismática Católica Internacional, seguida no Brasil pela coordenação na América Latina e pela Coordenadoria Nacional do movimento. As decisões da Coordenadoria Nacional devem ser acatadas e seguidas em todo o país, também representado por coordenadorias, em nível estadual, diocesano e municipal. Essas coordenadorias são formadas majoritariamente por leigos.

A Coordenadoria Nacional tem constantemente reiterado a importância da padronização do movimento, seus rituais e sua doutrina, na tentativa de estabelecer um sistema de crenças e ritos a serem seguidos pelas bases. Um elemento importante desse esforço é a formação das lideranças. Para isso criaram-se escolas de formação nos dons do Espírito Santo. A “formação" passa a prevalecer como exigência da hierarquia para o reconhecimento das lideranças. O fiel deve comprovar competência para desempenhar a função de coordenador/pregador através de uma graduação formalizada pela cúpula, após a participação em cursos organizados pela coordenadoria nacional. Para cada tipo de liderança há uma preparação específica (Sales 2003).

Forma-se, então, um corpo de especialistas da RCC, que é responsável pela disseminação do sistema de crenças do movimento. Além disso, apesar de a RCC ser um movimento em que a experiência do contato com as figuras divinas é central, seus rituais também possuem uma exaustiva parte "didática", composta por uma série de palestras sobre o sistema de crenças do movimento ministradas pelos pregadores e lideranças formados na RCC. Os participantes são constantemente informados sobre a fundamentação de suas crenças e práticas. Assim, o sistema de crenças carismático é disseminado desde o topo da hierarquia até as suas bases.

Especificamente no que se refere às aparições de Nossa Senhora, a estrutura hierárquica e burocrática da RCC é fundamental para a disseminação da crença e devoção a estes fenômenos. Exemplos disso são as justificativas teológicas realizadas por René Laurentin que estão presentes nos discursos dos carismáticos. Assim, a partir do contato do teólogo com o movimento nos Estados Unidos, onde está localizada a coordenação internacional, tem início a reprodução e a disseminação das justificativas para a devoção às aparições que são observadas entre os carismáticos no Brasil.

Dessa maneira, se Laurentin e João Paulo II contribuem para a formação da legitimidade deste tipo de fenômeno a partir da produção da devoção, a RCC tem papel fundamental na disseminação dessas crenças, fazendo-as chegar aos 
membros da base do movimento. A intermediação deste movimento é, pois, fundamental.

A RCC, apesar de ser um movimento da Igreja Católica, possui alguma independência em relação a ela, por isso serve para a discussão sobre os corpos intermediários - no caso, os novos movimentos leigos - na instituição católica. Os movimentos de mediação são centrais na sociedade contemporânea, inclusive na Igreja Católica. Consideramos como mediadores os movimentos leigos ligados à Igreja Católica, mas que possuem certa independência em relação a ela, cujo melhor exemplo é a Renovação Carismática. Esse movimento é composto por uma estrutura hierárquica independente e paralela à instituição católica, à qual seus membros devem obediência.

A concepção de corpos intermediários vem da sociologia das instituições e, segundo os estudiosos, estes elementos ocupam um lugar cada vez mais importante nas últimas décadas, sendo considerados como uma barreira contra o autoritarismo e centrais na constituição da democracia pluralista, garantindo ativamente a liberdade dos cidadãos. Segundo Palard (2006), as associações têm como principal função estabelecer a ligação entre o Estado democrático e os cidadãos e protegê-los contra o despotismo. Nesse sentido, elas são concebidas como uma esfera intermediária entre o poder e os cidadãos, responsável pelo elo entre eles, mas também garante das liberdades e da proteção.

A questão é se podemos transpor estes princípios de mediação entre indivíduo e instituição presentes na sociedade política para as relações entre a Igreja e o indivíduo, considerando que a instituição católica está hierarquicamente estruturada sob as bases de um centralismo - do Vaticano - cujo poder despótico não deve ser questionado devido ao dogma da infalibilidade papal. Segundo Palard (2006), esta transposição apenas pode ser feita dentro de certos limites, sobretudo no que se refere à manutenção da unidade disciplinar e doutrinária, que deve primar sobre a liberdade, não podendo ser dividida nem negociada. Dessa maneira, o poder na Igreja Católica continua sendo exercido de forma hierárquica e centralizada, sendo sustentado pelos princípios da verdade divina e da unidade doutrinária, dos quais a instituição não abre mão. Assim, a participação dos leigos e a ação dos novos movimentos somente podem ocorrer dentro de determinados limites impostos pela hierarquia, sendo o principal deles a fidelidade à doutrina católica.

Dessa forma, o movimento carismático deve fidelidade a esta doutrina, e é justamente porque se adequou a ela que consegue se disseminar com grande força a partir de meados da década de 1990. Apesar de ser um movimento bastante polêmico em seu início, ${ }^{9}$ ele não rompe com a doutrina católica, pelo

9 A polêmica estava centrada em duas características da RCC: a crença no contato direto com o Espírito Santo e as características emocionais e entusiastas dos rituais nos momentos em que se cria na presença e contato com o divino. 
contrário, os carismáticos fazem questão de se proclamarem católicos, enfatizando dogmas caros a essa religião, como os sacramentos e a infalibilidade do papa.

A RCC realiza a mediação entre o indivíduo e a instituição, organizando e divulgando rituais, bem como elementos simbólicos e informações referentes às aparições. Entretanto, essa mediação é estabelecida dentro dos limites doutrinários estabelecidos pela Igreja. Isso não impede, porém, a maior autonomia destes movimentos na atualidade. Inclusive, podemos pensar na importância deles para a manutenção do poder da Igreja Católica, pois são justamente os movimentos leigos que mais crescem e arregimentam fiéis nas últimas décadas.

Além disso, os movimentos leigos de mediação, nos moldes da RCC, demonstram um funcionamento religioso mais reticular e menos hierarquizado, menos centralizado e mais segmentar. A presença do movimento carismático por todo o país demonstra esta reticularidade, estando presente em numerosas paróquias. Houve uma estratégia desenvolvida pelo movimento para implantar seus rituais no maior número de paróquias, objetivo alcançado com bastante sucesso. Assim, os grupos de oração da RCC estão presentes em todo o país, sendo organizados e liderados por leigos da localidade, que compartilham a realização de práticas rituais com os sacerdotes locais.

A organização hierárquica e burocrática da RCC, bem como sua presença reticular na Igreja possibilita que as ideias e crenças que servem de fonte de legitimidade para as aparições circulem e sejam disseminadas. A sua reticularidade contribui para a organização das peregrinações, e permite que as informações sobre a realização dos rituais e palestras sobre aparições, bem como as crenças e devoções associadas a elas se disseminem de forma bastante eficiente.

\section{CONSIDERAÇÕES FINAIS}

A centralidade da ação da Igreja Católica para a legitimidade das aparições da Virgem Maria foi observada ao longo de todo o artigo. A partir da leitura das obras de autores franceses, constatamos que esta interferência acontece desde o século XIX, momento em que representantes da alta hierarquia católica contribuíram sobremaneira para a formação de um modelo de manifestações marianas.

Esta interferência mantém-se na contemporaneidade. Assim, a instituição católica busca não perder seus fiéis e não diminuir seu poder por meio de novos agentes e formas de ação. Observando os argumentos e devoções empreendidos pelos agentes católicos e a intermediação realizada pelos movimentos leigos, constatamos que novos modelos de ação contribuem para a manutenção dos fiéis no catolicismo, tornando-os fundamentais para a Igreja na atualidade. A instituição católica não abandona elementos importantes de sua doutrina, 
pelo contrário, eles permanecem como eixo central de suas ações e discursos. Porém, passa a utilizar estratégias e práticas que pertencem a esse novo contexto, como as novas peregrinações, as evidências científicas e os movimentos de mediação.

$\mathrm{Na}$ verdade, a incorporação do novo serve para a continuidade da Igreja Católica, que não abandona seus valores, símbolos e crenças, mas acrescenta a eles o uso de práticas pertencentes ao mundo contemporâneo para manter seu poder e influência. Isso foi observado ao longo deste artigo em vários fatores, como nas políticas e práticas eclesiásticas em relação às aparições da Virgem Maria, especificamente nas posturas adotadas por membros iminentes da Igreja. O aparato metodológico e argumentativo de Laurentin é exemplo disso, sempre buscando comprovar a autenticidade das aparições com base em dados de cunho científico. As atitudes do papa João Paulo II também mereceram destaque. Ele, pela sua própria prática de peregrinar, recoloca a peregrinação e o movimento como centrais no catolicismo. Por fim, a centralidade dos movimentos de intermediação para o catolicismo na atualidade também foi notada.

\section{BIBLIOGRAFIA}

AAVV, 1992, La Vierge Marie dans la piété du peuple chrétien depuis Vatican II. Paris, Médiaspaul. ALBERT-LlORCA, Marlène, 2001, "Les apparitions et leur histoire", Archive des Sciences Sociales des Religions, 116: 53-66.

ALBERT-LLORCA, Marlène, 2002, Les vierges miraculeuses: Légendes et rituels. Paris, Gallimard. AlMEIDA, Tânia Mara, 2004, Vozes da Mãe do Silêncio. Brasília, CNPq e Pronex.

BARNAY, Sylvie, 1999, Le Ciel sur la Terre: Les apparitions de la Vierge au Moyen Âge. Paris, Les

Editions du Cerf.

BARNAY, Sylvie, 2002, La Vierge: Femme au visage divin. Paris, Gallimard.

BILLET, Bernard, Joachin-Marie ALONSO, Boris BOBRINSKOY, Marc ORAISON, e René

LAURENTIN, 1976, Vrais et fausses apparitions dans l'Église. Paris, Lethielleux.

BOUFLET, Joachim, 1999, Medjugorje ou la fabrication du surnaturel. Paris, Salvador.

CLAVERIE, Elisabeth, 2003, Les guerres de la Vierge: Une anthropologie des apparitions. Paris, Gallimard.

GILLET, Claude, 1994, La rumeur de Dieu: Apparitions, prophéties et miracles sous la Restauration. Paris, Imago.

HARRIS, Ruth, 2001, Lourdes: La grande histoire des apparittions, des pèlerinages et des guérrisons. Paris, JC Lattès.

HERVIEU-LÉGER, Danielle, 1999, Le pèlerin et le converti: La religion en mouvement. Paris, Flammarion. 
LAURENTIN, René, 1957-1961, Lourdes, documents autentiques. Paris, Lethielleux, 7 vols.

LAURENTIN, René, 1965, Lourdes, histoire autentique. Paris, Lethielleux, 6 vols.

LAURENTIN, René, 1970, Pontmain: Histoire autentique. Paris, Lethielleux.

LAURENTIN, René, 1976, La médaille miraculeuse: Documents autentiques. Paris, Lethielleux.

Laurentin, René, e Michel CORTeville, 2002, Découverte du secret de La Sallete. Paris, Fayard.

LAURENTIN, René, e Patrick SBALCHIERO, 2002, Dictionnaire des miracles et de l'extraordinaire chrétien. Paris, Fayard.

PALARD, Jacques, 2006, "Médiation et institution catholique", Archives de Sciences Sociales des Religions, 133: 9-26.

PELLETIER, Denis, 2005, "Laurent Frölich, Les catholiques intransigeants en France", Archives de Sciences Sociales des Religions, 131-132: 215-311.

PORTIER, Philippe, 2006, La pensée de Jean-Paul II. Paris, Les Editions de l'Atelier.

ROCHA, Luís Miguel, 2010, Bala Santa: O Atentado a João Paulo II. Rio de Janeiro, Agir.

SALES, Lílian, 2003, Ou Quente, ou Frio, Senão Vomitar-te-ei: Um Estudo das Práticas Rituais na RCC. São Paulo, Universidade de São Paulo, dissertação de mestrado.

SALES, Lílian, 2009, "Redes e peregrinações: a circulação nas aparições marianas", Ciências Sociais e Religião, 11 (11): 59-91.

STEIL, Carlos Alberto, Cecília MARIZ, e Mísia REESINK, 2003, Maria entre os Vivos. Porto Alegre, Editora da UFRGS.

WOJTYLA, Karol, 1987, La Mére du Redempteur: Lettre encyclique Redemptoris Mater, 25 Mars 1987. Paris, Le Centurion.

ZIMDARS-SWARTZ, Sandra L., 1991, Encountering Mary: From La Sallete to Medjugorje. Princeton, Princeton University Press. 